\title{
Use of Twitter as an Educational Resource. Analysis of Concepts of Active and Trainee Teachers
}

\author{
Lina Higueras-Rodríguez ${ }^{1, *}$ (i) , Marta Medina-García ${ }^{1}[$ and \\ $\mathbf{M}^{\mathrm{a}}$ del Carmen Pegalajar-Palomino ${ }^{2}$ (D) \\ 1 Department of Education, University of Almeria, 04120 Almeria, Spain; mmedina@ual.es \\ 2 Department of Pedagogy, University of Jaen, 23009 Jaen, Spain; mcpegala@ujaen.es \\ * Correspondence: mlinahr@ual.es
}

Received: 13 July 2020; Accepted: 3 August 2020; Published: 5 August 2020

check for updates

\begin{abstract}
The use of innovative tools is a key element in the improvement of the educational process, and consequently, the use of social networks as a means of training to improve not only the learning of students, but also to improve the expectations of the teacher. Therefore, in this research we tried to investigate the incidence of social networks as facilitators of resources and didactic/playful experiences. Starting from a qualitative methodology, a descriptive-interpretative study of the information from 31 interviews with both primary education teachers and future teachers who were in training and in their last year of initial training was approached. The results indicate that the interviewees confirmed the great usefulness of social networks as educational resources and for teacher communication. The possibilities of social networks within the educational field are overly broad. They become a way of interaction between teacher and student, encourage dialogue, share didactic resources, favor collaborative learning, and develop communication skills in all aspects. In short, these are results that have a special incidence and impact on the field and social development, since we are referring fundamentally to the improvements that are produced in interpersonal relations.
\end{abstract}

Keywords: social networks; educational resources; school; teachers; teacher training

\section{Introduction}

The continuous changes demanded by the information society and the expansion of numerous social networks or virtual communities have been a key factor in the use of these for news information, buying and selling of products, and communication, among other aspects [1]. Therefore, the context in which we operate has been changing in the form of communication and that is why education does not escape from it either. Throughout the years, the social changes that are taking place have demanded new teaching models [2]. These models require a process of innovation and teacher training to respond to social demands. This has been linked to the use of new technologies such as the electronic portfolio, virtual teaching, and social networks [3].

The application and development of new technologies aims to develop certain skills in students and improve the quality of teaching [4]. All of this falls within the framework of the European Higher Education Area (EHEA).

As mentioned by Gómez et al. [5], ICTs are not in themselves the components of teaching innovation, but the way they are used and the results they achieve can be. Therefore, an innovative teacher is one who achieves better results by applying a new methodology to teaching.

For teachers to be well prepared in the use of ICT as an educational element, they must be prepared from their initial training. The first stage of a teacher is where he or she must acquire the ability to learn, innovate, teach, etc. [6,7]. 
One of the challenges facing education today is to rebuild the educational space and adapt it to a society of continuous change. Social networks, which constitute a series of more significant tools of the web 2.0, cannot be ignored for their study, since they are a resource that motivates students and are a didactic possibility that any teacher should know. That is why a modification of the roles of both teachers and students is demanded, which implies the adaptation of teaching and learning strategies that include web 2.0 and its different tools, as a fundamental part of educational practices. Social networks have become a resource that allows for collaborative learning and implies spaces for the exchange of information that promote cooperation [8].

In this study, the incidence of social networks as a learning strategy and in the knowledge and use of didactic/playful resources is presented. The intention was to show how the subjects interviewed (teachers and teachers in their initial training) have been incorporating the use of social networks into their educational practice, and relate it to their teaching-learning style, perception, assessment, and usefulness.

\section{Theoretical Framework}

\subsection{Importance of Social Networks for Social Development}

The importance of social networks in the social field is reflected in many aspects included in their definition. In a broad sense, social networks can be defined "as a social structure formed by people or entities connected and united among themselves by some type of relationship or common interest" [9] (p. 2).

Currently, exchanging information is becoming commonplace, society is undergoing accelerated changes, in part, due to the great advance of information and communication technologies (ICT) [10]. Social networks have become an instantaneous and effective means of communication, through which the population's participation increases in a social, civic, and political way [11]. In this sense, we are affected using the Internet in all areas of our lives [12].

The use of ICT has led to information being managed at a planetary level, transforming the social, political, and economic spheres. It is indisputable how human relations have changed, and how they have been structured around social networks and the tools offered by the web 2.0. [13]. We are all aware that social networks have a huge impact on our society. Social networks have transformed the way people communicate and socialize. Social networks also change the lifestyle of a society [14].

The relationship between the growth and implementation of ICTs and social development is so close and indissoluble that it is comprehensively addressed in the United Nations' Sustainable Development Goals (SDG) [15]. It relates to SDG 10 by referring to the potential of ICTs to help reduce inequality both within and between countries. SDG 11 states that ICTs will be essential in providing innovative approaches to managing cities more effectively, stating that the use of ICTs to make cities greener and more sustainable is also vital to the sustainability of the planet. It is understood that ICTs are a guarantee for sustainable consumption and production (SDG 12), as well as for the conservation of oceans, seas, and marine resources (SDG 14). In this sense, ICTs have a relevant role to play for the conservation of the planet in terms of ecosystems and climate change (SDG 13 and 15), but also play a major role in social and interpersonal development itself as a key to promoting peaceful and inclusive societies (SDG 16) and establishing means of implementation and revitalization for the global partnership for sustainable development (SDG 17). Ultimately, ICTs are crucial to the achievement of all SDGs as they are catalysts for all three pillars of sustainable development: economic growth, social inclusion, and environmental sustainability.

\subsection{Approach to the Concept of Social Networks}

To understand the concept of a social network, a differentiation must be made between it and the knowledge communities, since their structure, use, and functions within the educational environment become two tools with significant differences. On the one hand, in social networks, users build a profile and allow the sharing of all kinds of data and information. Therefore, they become ideal spaces for the 
communicative exchange between users [16,17]. On the other hand, knowledge communities are web 2.0 spaces, whose basis is the same as that of social networks, but their objective and operation is quite different [18]. Knowledge communities are virtual spaces for collaboration, whose aim is to promote interaction between users, whether for professional, educational, or entertainment purposes. They are spaces in which users share information with the rest of the Internet users, in a disinterested way and without the need to register. Without the need to create a profile, they can interact anonymously with the rest of the members of the community $[16,19]$.

Social networks can become a means of communication between society, school, and family. According to De Haro [10], the aim is to take advantage of the links generated in social networks to strengthen possible interactions between the school and social agents. For this reason, pedagogical training must seek the social context in which teaching takes place, based on diverse and flexible training strategies. To respond to the multiple and diverse individual, disciplinary, and contextual needs that teachers may encounter [20].

Another aspect that is considered important is that social networks are used to achieve a more open classroom concept, in which architectural barriers are not an impediment to student learning. Rather, it is intended to go beyond the school [21].

\subsection{Potential of Educational Social Networks.}

Working in the classroom using educational social networks offers several very considerable advantages from an educational point of view. From the viewpoint of Santamaría [22] and Mero et al. [23], some advantages are highlighted:

- They offer interactive and effective tools for teaching and learning. In addition, the integration of tools and applications (blogs, chat, email, forums) by these services provides a very suitable scenario for the practice of most of the activities of working in online environments.

- They enable the teacher who uses these resources to teach his or her students to acquire skills to stand on their own feet, and to continue learning in a world undergoing an accelerated process of change and transformation.

- Not only do they enable the transmission of knowledge and collaboration between people. Moreover, they develop technological skills that are essential for operating in diverse and complex contexts.

- Enable students to develop skills and abilities such as socialization, teamwork, or the importance of sharing.

- They help teachers and students to become aware of the importance of digital identity and the social processes of participation, opinion formation, and decision-making that characterize an advanced and democratic society.

- They allow students to learn by doing things. Cognitive processes evolve through the transformation and manipulation of information. High-level cognitive skills are developed, such as reasoning, the ability to synthesize and analyze, and decision-making.

- From the teachers' point of view, they constitute a magnificent opportunity for learning, permanent training, and professional development.

- They offer unparalleled opportunities for the dissemination of educational and institutional activity of schools.

\subsection{The Teacher's Role in Using Social Networks for Learning}

For social networks to become part of the educational transformation, it is important to emphasize that the teacher has a significant role. They participate in the process of generating knowledge together with the students in a constructed and shared way. That is why learning-centered processes are related to organization and understanding, since learning is the result of interpretation $[7,24]$. 
However, in this type of learning situation, the teacher's effort is focused on helping students to develop skills and knowledge using new teaching schemes, becoming a guide in the teaching and learning process. In turn, students are more autonomous in their learning. Similarly, the change caused by social networks in the role of the teacher is decisive. Artero [25] stated that the teacher is no longer the source of transmission of knowledge to students. All the knowledge we want resides on the Internet and teachers must be aware of this and legitimize their position in the classroom as a guide, tutor, and mediator in learning.

A commitment is needed on the part of the teacher to develop skills and competences that will allow him/her to carry out his/her work. As mentioned by Artero [25] "not to be anchored in methods/systems that are now outdated due to the informative, communicative, and interactive progress offered by the Net and, even more so, by social networks".

\subsection{The Student's Role in Social Networks, Their Learning Styles, and Strategies}

Regarding the role of students in social networks, and since they are considered the central axis of the teaching-learning process, it is necessary that they develop skills, abilities, and competence to access information sources and make use of them for their learning.

Students in the field of social networks need to develop skills in assimilation, interpretation, and reproduction of information. They need to recognize their learning styles, since each has a different style of perceiving and processing at a different pace. This implies that, depending on the context and type of information, the student combines learning styles: visual, auditory, or kinesthetic [23].

This allows us to understand the relationship between the concept of learning styles that different authors have built and what students develop when using tools such as social networks. Geijo [26] and Guild and Garger [27] defined learning styles as the set of aptitudes, preferences, tendencies, and attitudes that a person must have in order to do something that is manifested through a behavioral pattern. In addition, they have different skills that distinguish them from other people under a single label in the way they communicate, think, learn, know, and teach.

Learning strategies are characterized as procedures through which information can be acquired and integrated with existing knowledge; they require an effort, are voluntary, essential, and necessary in educational settings, because, in general, they help to improve academic performance [28].

Therefore, social networks, and in general Web 2.0 tools, can be considered a learning strategy, because they would have the role of information and media facilitators for integration and communication; on a voluntary basis, students would access them and give an added value to their learning processes.

Torres [29] considered that learning strategies are procedures that learners use in a conscious, controlled, and intentional way as flexible tools for meaningful learning and problem solving; this encourages the formation of learning communities in which learners investigate thematic content, as well as information of personal interest, and become leaders and responsible for their learning.

Therefore, the objectives of our research are:

- To know the incidence of social networks as a teaching and learning strategy;

- To value the degree of importance of social networks for teachers;

- To know the different educational resources available in the social networks;

- To know what kind of training is acquired through social networks as an educational and training method.

\section{Method}

Based on authors such as Sandin [30], Flick [31], and Denzin and Lincoln [32], among others, we selected a qualitative methodological approach because it helps to determine the meaning given to phenomena-to discover the meaning and the way in which people describe their experience of a particular event. In this sense, and in accordance with the objectives of the research, we believe 
that it allowed us to know details of the subject studied that would otherwise be impossible to reach. We understand that it facilitated access to the thinking and reflections of teachers, giving us insight into their conceptions and assessments of the power of social networks to facilitate educational resources and experiences. We were interested in knowing the different perspectives that teachers (future and current) have on the impact of social networks on the knowledge and use of resources, and didactic/playful experiences.

The data were obtained through in-depth interviews supported by a script developed for this research, validated by a system of judges. The questions were semi-structured and open-ended, all focusing on the objectives guiding the research. The interviews were recorded and transcribed verbatim and lasted between 50 and 100 minutes. Table 1 illustrates the interview script used for the research.

Table 1. Semi-structured interview script questions.

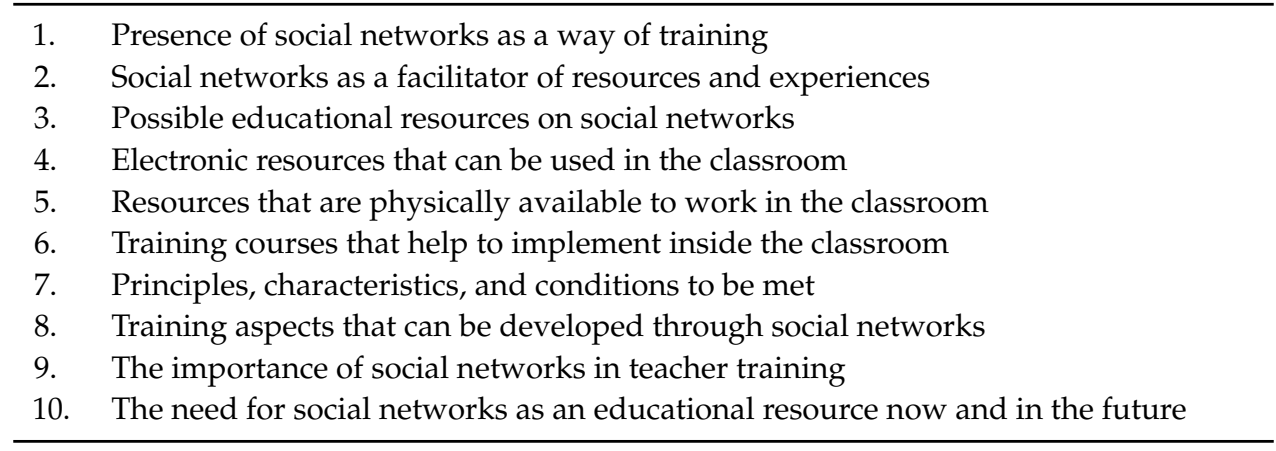

Source: own elaboration.

\subsection{Subjects of the Research}

For the selection, two profiles of subjects to be interviewed were considered: the first one being teachers who were in the primary education stage currently working. The second profile included future primary education teachers who were in their last year of training and who were doing their internship in the final stage. These two profiles were considered similar for the research because they offered a complete vision of both initial training and professional development.

We considered that from these different perspectives we could obtain a more complete vision of what happens in the classrooms of primary education schools with respect to the use and application of didactic resources and tools by being able to count on the vision of the teachers themselves and also that of the future teachers. The latter, when carrying out the "external practices" can observe the incidents and actions in the classrooms. They could also provide information about the presence of social networks as a way of training and as a resource used in their own learning.

Several conditions were considered for the selection of the subjects:

(a) Teachers:

- They teach in primary education.

- At least 5 years of service.

- They work in schools that carry out innovative activities and that the schools have innovation flows.

(b) Future teachers:

- Last year of training.

- They were in their final training period.

In addition, other aspects such as intentionality, motivation, timeliness, accessibility, personal interest, relevance, and appropriateness were considered. Relevance and suitability are the 
most significant, since they refer to the choice of the subjects that could provide the best and most information to the research. With respect to suitability, it refers to having the necessary data for the most comprehensive understanding possible.

Finally, 31 subjects participated (16 teachers and 15 future teachers).

\subsection{Data Analysis}

The technique used was content analysis, as it is one of the most effective procedures for analyzing the textual material of the interviews [33]. This technique was defined by Bardin [34] (p. 7) as "a set of methodological instruments increasingly perfect and in constant improvement applied to extremely diversified discourses (content and continents). The common factor of these multiple and multiplied techniques is a controlled hermeneutic, based on deduction: inference".

Content analysis aims to discover the meanings of documents [35]. To carry out this model of analysis, Krippendorff [36] showed a type of process for content analysis: data formulation (determination of units, sampling, and recording), data reduction, inference, and analysis. However, the three phases he proposed were followed Bardín [34]:

1. Pre-analysis;

2. Use of the material;

3. Treatment of results, inference, and interpretation.

In the first one, the material was prepared, transcribing the interviews literally; in the second one, the categorization process was carried out, delimiting the units of meaning, using the word, the sentence, and the paragraph, and establishing codes.

Table 2 shows the relationship between the categories and their respective codifications. In addition, the definition of each one of them is shown.

Table 2. Code System.

\begin{tabular}{|c|c|}
\hline Category and Code & Definition \\
\hline $\begin{array}{l}\text { Knowledge } \\
\text { KN }\end{array}$ & Teachers' knowledge of social networks as a training tool \\
\hline $\begin{array}{l}\text { Importance } \\
\text { IM }\end{array}$ & Level of involvement of social networks in the teaching and learning process \\
\hline $\begin{array}{l}\text { Electronic Resources } \\
\text { ER }\end{array}$ & $\begin{array}{l}\text { Possible educational resources. Electronic resources that can be used in } \\
\text { the classroom }\end{array}$ \\
\hline $\begin{array}{l}\text { Physical Resources } \\
\text { PR }\end{array}$ & $\begin{array}{c}\text { Possible educational resources. Resources that are physically available to work in } \\
\text { the classroom }\end{array}$ \\
\hline $\begin{array}{l}\text { Training Acquired } \\
\text { TA }\end{array}$ & Training aspects related to the use of social networks in education \\
\hline
\end{tabular}

Finally, in the third phase, data processing was carried out with the help of the qualitative QSR program Nvivo 12 Plus, which facilitated the elaboration of the results report. In this report, the findings are shown, supported by textual quotations following the guidelines offered by McMillan and Schumacher [37].

\section{Results}

Figure 1 shows the different categories used in the interview, which cover all the general points dealt with in the content analysis.

The different categories analyzed were significant for both groups of subjects. The categories most commented on by teachers were electronic resources to be used in the classroom and knowledge about social networks. While for the future teachers, it was the importance of social networks in the educational process and electronic resources.

The following are the results by research objectives. 


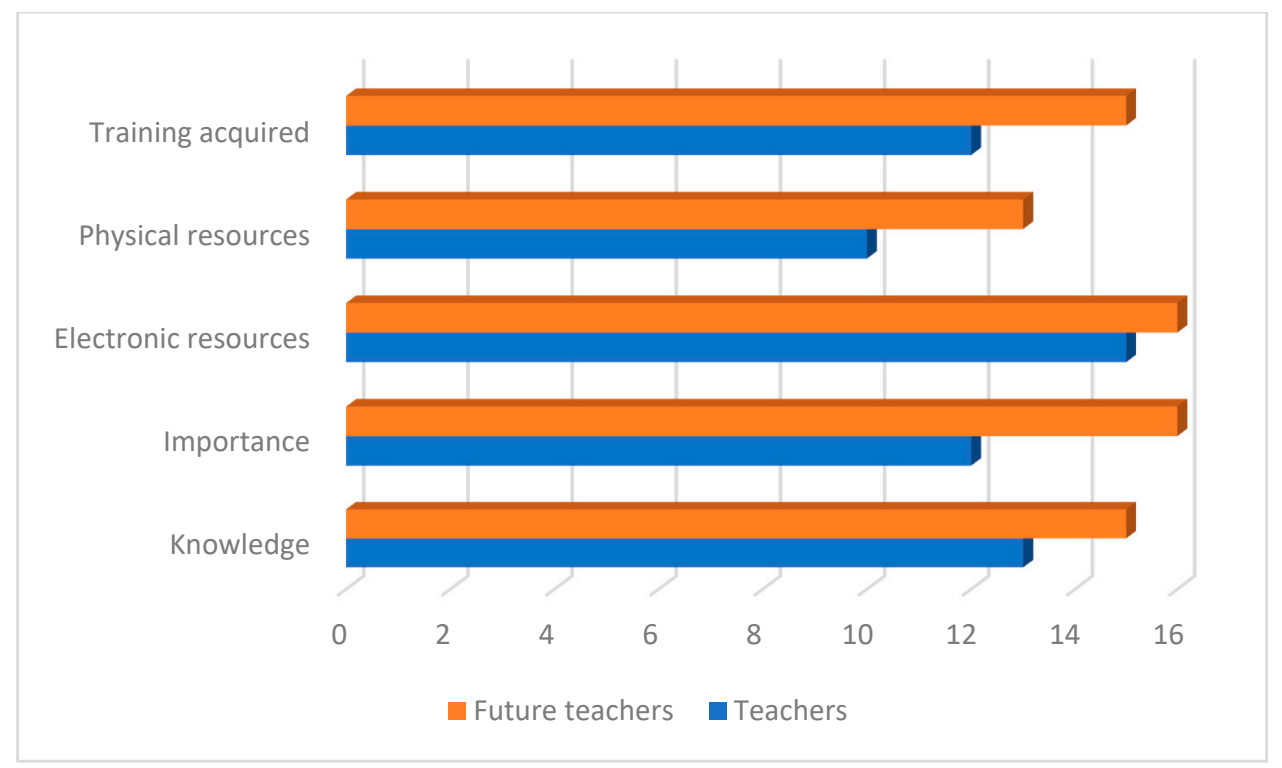

Figure 1. Overview of categories. Source: own elaboration.

\subsection{Knowledge of Social Networks as a Teaching and Learning Strategy}

Many teachers make use of social networks as an educational resource. It is a channel of continuous information where you can be in contact with other professionals in the educational field and share experiences and resources that can be adapted and implemented in different school classrooms. That is why we asked the different interviewees about their importance, or not, as a resource available to everyone. The use of social networks within the educational environment is increasingly in demand. It is a way of accessing different tools and resources that other students are using and that can be especially useful for our class. Figure 2 shows that most of the subjects interviewed (teachers and teachers in training) tend to use social networks as a teaching tool.

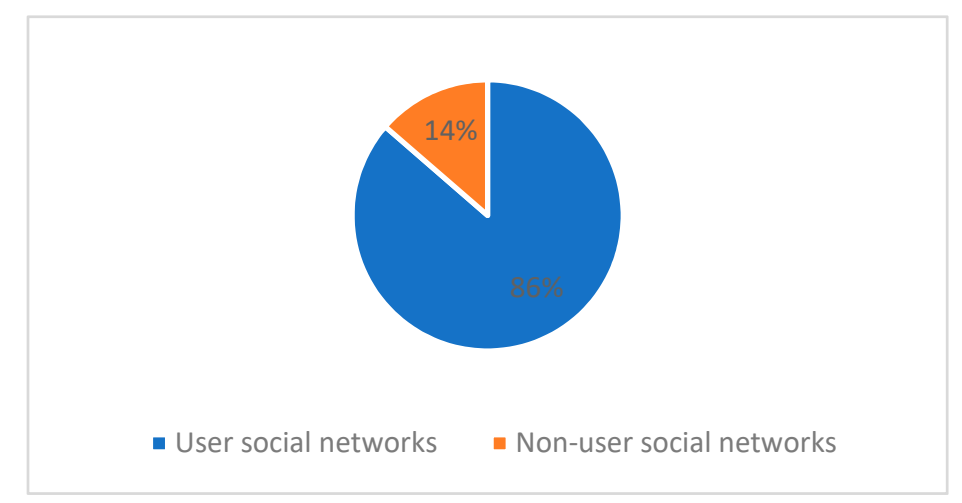

Figure 2. Use of social networks as an educational tool by the interviewees. Source: own elaboration.

Most of the interviewees use different social networks for their training and to share experiences. The most used networks are Twitter and Facebook, because their interface is quite simple and they can be connected and share resources quickly. They use hashtags to identify the content they want to view and have quick and efficient access. They also use groups where it is easier to connect with other professionals in the educational world and have that ease of communication between them.

"The social networks I normally use are Twitter and Facebook. I think they're two powerful tools for teacher communication." (T3) 
"I prefer to use Facebook because through group creation it is easier to be connected with other teachers." (T14)

"I like Facebook and Twitter. I use them both to know what other teachers are doing and to learn from them." (S12)

Some interviewees talked about different resources and social networks apart from Twitter where they are in contact with teachers, such as "Orientación Ándujar", "Active teaching", "Innovative teachers", "Orienta red", "Maestros 25", and can see what is being worked on in different schools:

"I use Facebook too. There are many pages like Active Teaching, Innovative Teachers, Networking, Masters 25, etc. I actually use Twitter and Facebook to find out what other teachers are doing." (S13)

"What I use a lot is Orientación Andújar. I follow him on Facebook and Twitter, and they have a lot of material." (S15)

Teachers-in-training use many electronic resources for training because they believe that the application of this type of tool is convenient for their training, since it favors aspects such as communication and participation, helping the student to move from the academic context to the real world.

"I consider the use of social networks essential to my training." (S2)

"[ ... ] I can see through the social networks what I've been learning since the theory. It is a way of looking at educational practice." (S8)

This aspect is also characteristic of practicing teachers because the use of social networks is especially useful for improving their professional development.

"I use it a lot for my professional development. We teachers have to keep moving forward." (T9)

In short, in view of the results obtained, we can state that in general all teachers, both in training and in practice, are inclined to use social networks for their training and professional development as teachers.

\subsection{Importance of Social Networks for Teachers}

The importance of social networks for teachers in training is present in the results obtained, since they consider that they are interactive tools since they allow interaction in the publications of other users, and that through them debate and participation is generated. Furthermore, it encourages the development of skills and abilities such as socialization and teamwork.

"Social networks are very important to me because they help me to know what teachers are doing and I can maintain communication with them." (S1)

"The use of social networks for teachers is very important because they can be in contact with each other, see what they are working on in the classroom, improve their content through feedback and be able to work as a team, even if that person is not in your same school. A great learning community is generated." (S10)

They said it is a great resource to know what other professionals are working on and how they are using it in their classes.

"It is a good resource to have teachers because you can get experiences from other teachers about methodologies and resources that interest you, but you always have to know how to use it." (S12) 
Social networks can be a way of training education professionals as they offer indirect and affordable training. Teachers must be in continuous training to be able to adapt their contents to the reality of the classroom.

"Social networks are a great resource to share educational experiences and see what other teachers are working on. It is a great opportunity to learn in an indirect way and to know how you do it and to be able to adapt those contents to your classroom reality." (S1)

Thus, you can get to know what other people are working on and be in contact with teachers regardless of where they are:

"From the new technologies there is a great variety of opportunities and there are teachers who are doing something new for example in Galicia may be sharing information with teachers in Andalusia. I do think that sharing methodologies through networks and ideas can bring positive things. I think it is very useful and powerful." (S6)

Another aspect that they considered very important is that they encourage the development of technological skills, because not only do they learn in a dynamic way through participation, but they also encourage the use of different tools that help them in their professional development.

"These are used for communication between professionals, but also for finding resources and tools.

I consider that it improves my technological competence." (S12)

While for practicing teachers, the main reason for this educational use is to be in contact with other classmates who use active and playful methodologies in class and to see how they apply them. In this way, the teacher who needs it can adapt it to the needs of his or her students.

"I use social networks as a teaching medium because I like to see what other people are working on and see if I can adapt it to my class. The truth is that a window to see what they do and to make known what you do in the classroom." (T11)

They saw it as a teaching tool and saw an opportunity to publicize their work and receive feedback from colleagues in the same profession. It is a great resource for communication between professionals.

"[ ... ] also, as a teaching tool. I see this as a great opportunity to show and make known what we are working on in the centre and at the same time also to take ideas from other centres that are working on project-based methodology. The truth is that this type of network is particularly good for communication between teachers [ ... ]" (T4)

"What we do is make known what we are working on so that other teachers elsewhere can see it and whether it is useful for their classroom and be able to adapt it to that context [ ... ]" (T6)

In addition, it is a window to tell learning experiences and have a feedback that helps to improve different aspects to make the process more effective.

"[ ... ] It's a continuous feedback because you can show how you do it and people are helping you."(T11)

Moreover, it offers resources and experiences that any teacher can adapt to the needs and interests of their students.

"I keep my own blog [ ... ] I share these tools so that other teachers can see them and adapt them to their needs and interests $[\ldots]$ " (T5)

In short, practicing teachers and teachers in training value the great importance that the use of social networks has for teachers in general, since it is not only used for communication between them, but also for sharing experiences and resources that can be useful for working in other educational centers. 
4.3. To Know What Type of Training is Acquired through Social Networks as an Educational and Training Route

Another aspect to consider is that some teachers not only use it to learn and to make resources available, but also to be in contact with the students of the school and with their families. The school itself invests in new technologies and teachers make use of this:

"We try to always be in connection with the family and the children so that we can exchange knowledge.

Then we have an internal chat at family level where I can communicate [ ... ]" (T4)

They maintain communication through a blog where they share the material worked on in class and parents can see what their children are doing and maintain direct contact with the teacher through email.

"We have a blog for each course from 3rd to 6th where each student has their own email and we are in constant contact with them and their families [... ]"

They said it is a way of sharing what you do. It is not good to work for just one, but to open opportunities for other teachers to use these tools to achieve greater learning:

"I think so because it is a way to share what we all do, the ideas that each teacher has, because it can be through social networks. Not only talk to the teachers in the environment but see what they do elsewhere and that maybe I want to implement in the classroom." (S11)

Its usefulness was reflected in most interviews, as it is a great opportunity to know what other people are working on and to be in contact with other colleagues regardless of where they are:

"It is a great opportunity to get to know what is being worked on in other contexts and in other classrooms and to see if you are really interested and to be able to adapt it to your classroom needs." (T11)

"I find it very useful because it is good to be connected with other colleagues in other areas and see what they are working on and whether we can use it in our context." (T14)

In addition, some teachers have internal training in the use of the networks so that they can use them in their class. This training is open to teachers who request it, even if they are not from the same school:

"Very much so. In fact, one of the internal training we have to do here involves the Google Drive and it is very easy to use and we plan to have teachers come in who do not handle it so that we can teach them how it works. We also have "sites" that are like a Gmail platform where students can hang up to see their work." (T2)

All teachers in training agreed on the use of social networks for educational purposes, as another tool available to everyone and where they can learn a lot. However, other teachers did not see the use of social networks as a means of student and teacher learning and see it as an unnecessary waste of time:

"I'm not interested in social networks at all [ ... ] because it distracts me from what's important. And most of the social networks is because teachers start to publish a lot because I think you want to have that degree of social recognition and show that you know certain things. I can understand that, but I don't share that idea." (T9) 


\subsection{To Know the Different Educational Resources Available on Social Networks}

Physical resources are the tools that are physically found to work in the classroom. Every teacher, when faced with the teaching of a class, must select the resources and didactic materials he or she intends to use. Many think that the material or resources we choose are not important, since the important thing is to teach the class, but they are mistaken. It is fundamental to choose the resources and didactic materials adequately because they constitute fundamental tools for the development and enrichment of the teaching-learning process of the students.

"The resources we select are essential for the correct learning of our students." (T9)

There are many physical resources that were shown by the users for possible application and adaptation according to the characteristics of the students. From card games and their possible use, to games designed by the users themselves and showing them to others.

"KARUBA. Card game and its possibilities." (S8)

"Big Sun is a game to learn English from the Montessori methodology. The truth is that it is an especially important resource." (T1)

It was observed that professionals talked in the interviews about different electronic resources that can be used in the classroom, such as Trivinet, videos, video games, etc. resources that are found through the Internet or some digital platform. These are useful to develop their knowledge in a fun and unconventional way.

"Having fun with DIXIT, a classic! You learn through fun and game-based learning." (T6)

In turn, it can be used for initial learning or assessment, or for learning across the board, as is the case with virtual platforms.

"The Club Lia platform gives a results screen with details of time, correct and incorrect attempts for the evaluation of the student." (T5)

"The Club Lia platform includes video tutorials, internships and cross-cutting projects." (T5)

In addition, they offer many online resources for other teachers to use with their students.

"A selection of educational video games should be made they will serve to reinforce your students' knowledge and even have fun learning." (T2)

\section{Discussion}

The first two objectives of our research focused on understanding the impact of social networks as a teaching and learning strategy and assessing the degree of importance of social networks for teachers. These objectives are answered through the discussion of the following results of our research as well as related works.

Currently, from the educational research field, there is a predisposition in the use of the theory and methodology of social networks, and this is due to the findings of recent research that have shown the significant improvement of educational practice [38]. These questions were reaffirmed by the work of Richter and Dawley [39], which highlighted the need to investigate novel pedagogical processes, given the relevance of social networks in the construction of knowledge and their impact on student thinking.

Teaching practice requires an analysis of the here and now, of the factors that influence the classroom to detect the needs of each group and achieve student learning. As mentioned by Dutton and Hernandez [19], teachers need to know what is happening in their classrooms and try to improve their 
students' learning constantly. Likewise, the results of our research show how teachers, both practicing and in training, are aware of the different situations they must face to improve the educational process. One of the essential tools at present is social networks as a way of training and as an educational resource.

Although social networks were not originally developed or conceived for learning purposes, these have evolved in such a way that they have become an indispensable resource for teachers. The implications of the use of social networks for schools and academic activities today are fundamental. The study by Hunter and Hall [40], conducted on a sample of 154 teachers in the United States, indicated that teachers are increasingly using social networks, among other Internet applications, for their professional development, given aspects such as comfort and confidence. They are used as tools capable of modifying and innovating teaching/learning practices. The attention that social networking tools are progressively gaining in schools and practices and pedagogies requires adjustments in learning and teaching that educators and policy makers must constantly consider [7]. As shown in the results, their use is increasingly present in teachers of stages such as infant and primary, and even in the university stage. The latter is a double-track training path. On the one hand, with its use in university teachers; on the other hand, with the use of university students. In our case, with the use of teachers in training. In this sense, the promotion of social networks in the educational field affects the way we know and learn things. Such is the relevance of these aspects in the educational sphere that there are universities, like that of Pennsylvania, that are developing their own social networking sites for teacher training [41].

In relation to the literature and data collected, we found that social networks can become a means of communication between society, school, and family. According to Vidal et al. [42], the idea is to take advantage of the links generated in the networks to strengthen the possible interactions between the educational institution and the social agents. Therefore, pedagogical training must seek the social context in which teaching takes place, based on diverse and flexible training strategies [43], in order to respond to the multiple and different individual, disciplinary, and contextual needs that the teacher will encounter [20]. Teaching practice requires an analysis of the here and now, of the factors that influence the classroom, to detect the needs of each group and achieve student learning. As mentioned by Dutton and Hernández [19], teachers need to know what is going on in their classrooms and try to improve their students' learning in a constant way. In this sense, it is important to know the results of the research of Moghavvemi et al. [44], which confirmed that entertainment, information search, and academic learning are some of the main motivations of students to use social networks.

As Trujillo [45] said, the student needs to learn to solve problems, to critically analyze reality and transform it, to identify concepts, to learn to learn, to do, to learn to be, and to discover knowledge in a pleasant, interesting, and motivating way.

The results of our work speak to the use and importance of social networks in teachers-in-training. This is consistent with the research of Ozkan and McKenzie [41], who found that social networks and their popularity among young people make them attractive applications for higher education teachers. This aspect coincides to some extent with the findings of the study by Çam and Isbulan [46], which aimed to investigate how teachers-in-training are addicted to social networks, such as that of Facebook. This means that the importance that social networks have acquired in personal and professional development should be highlighted. Finally, the results concluded that there are significant differences in gender and age, with male teacher candidates in the final years more addicted to the use and relevance of these social networks. These data, and some of our results, contrast with the work of Ranieri et al., [47], who stated that little empirical research has been done on the professional use of social networking sites, specifically with reference to teacher groups on Facebook.

Research findings by Ozkan and McKenzie [41] concluded that it is essential for student teachers to understand and use social networks to develop their professional identity, as they are central to information literacy skills. These findings are consistent with the findings of Richter and Dawley [39], who found that attention should be paid to teacher training in this regard, given the potential it must help faculty teach, and students learn, in new dynamic ways. 
If we focus on objectives 3 and 4 of our research: to know the different educational resources available in social networks and to know the type of training that is acquired as a form of education and training, then we can conclude after the development of our research that there are many electronic educational resources that Twitter users mention to share resources and experiences. Regarding the type of training, it is part of a pedagogical training, promoting the acquisition of knowledge, skills, and abilities necessary for their professional performance.

Social networks are a resource for the exchange of resources and experiences [48]. In his research, he mentioned that the use of social networks encourages interactions among teachers and allows for the exchange of knowledge that helps and improves educational and social processes. Teachers are increasingly using social networks and other Internet applications to search for educational resources. The results of studies by Hunter and Hall [49] indicate in this regard that the factors predicting general commitment to social networks include, primarily, the comfort and confidence in the use of social networks. Authors such as Higueras-Rodriguez et al. [43] in their research have spoken of the importance of social networks as a fundamental resource in teacher education, by being present in the results obtained in our research. The proliferation of online resources and an increase in accessibility has led teachers to go online to connect, share ideas, and expand their own professional learning opportunities on social networking platforms [50]. All these investigations corroborate, together with our research, the importance of the use of social networks as an educational resource.

\section{Limitations and Future Works}

The main limitation found in our research is in relation to the territorial scope, since it has been developed in a specific city and further research could be carried out to find out the opinion of teachers on the use and importance of social networks as a training and educational resource. Another possible limitation could be the type of teachers in training, since only those who were in their last year and doing their internships were selected.

Therefore, it would be convenient to continue investigating and expanding the sample of teachers in training in the different university courses in order to know their opinion in depth and to make a comparison between courses and to investigate if there are differences as their training increases.

\section{Conclusions and Recommendations}

Social networks have completely transformed the way of transmitting information and communication, socializing with other professionals, and, in short, have changed the way of approaching professional development in all its facets. Most sectors have been affected by this revolution and the world of training has been no exception.

Social networks have become a resource that encourages collaborative and cooperative learning, generating different spaces for the exchange of information. One of the current challenges facing education in general is the reconstruction of new educational spaces and adapting them to the continuous changes taking place in society in general.

Social networks influence education since they are currently a fundamental tool; they allow education to be streamlined; they have changed the way we communicate; they have changed the way students can learn; they can be considered educational; they encourage dialogue and student participation, among other benefits; they allow teachers to teach students to learn by themselves by acting as learning guides; they are a means of communication, allowing students to feel more comfortable in their relationships between teacher and student; and they help develop digital and technological skills. However, among their most important disadvantages is that they produce addiction among students who use them.

One of the practical implications of this work is the applicability of the results to the educational field in general, since we consider that they go beyond the context of research and have an eminently practical character, and this is because the results show a general vision of what is being developed in the field of teaching, whether in practice or in their initial training. On the other hand, it offers 
different applications and tools available on social networks. In addition, web tools are commented on in the results. Likewise, these are relevant results for the knowledge of educational managers, as they show scientific evidence to knowledge and aspects that are dealt with in a divulging way. In short, this is an especially important training path for teachers, since they must continue to be trained.

To conclude, it can be said that the possibilities of social networks within the educational sphere are broad. They become a means of interaction between teacher and student, they encourage dialogue, share teaching resources, favor collaborative learning, and develop communication skills in all aspects. Although, to develop all these possibilities it will be necessary to have a good knowledge of technology and the training of teachers in the initiation to social networks in the educational field.

Author Contributions: Literature review and theoretical framework, L.H.-R.; methodology, L.H.-R. and M.M.-G.; analysis of results, L.H.-R. and M.d.C.P.-P.; writing-original draft preparation, L.H.-R. and M.M.-G.; writing-review and editing, L.H.-R., M.M-G. and M.d.C.P.-P.; visualization, L.H.-R.; supervision, L.H.-R.; project administration, L.H.R., M.M-G. and M.d.C.P.-P. All authors have read and agreed to the published version of the manuscript.

Funding: This research was funded by the Ministry of Education and Vocational Training. Department of Universities. Government of Spain, grant number FPU13/04096.

Conflicts of Interest: The authors declare no conflict of interest.

\section{References}

1. Mancini, T.; Imperato, C. Can Social Networks Make Us More Sensitive to Social Discrimination? E-Contact, Identity Processes and Perception of Online Sexual Discrimination in a Sample of Facebook Users. Soc. Sci. 2020, 9, 47. [CrossRef]

2. Zachos, G.; Paraskevopoulou-Kollia, E.-A.; Anagnostopoulos, I. Social media Uso in higher education: A review. Educ. Sci. 2018, 8, 194. [CrossRef]

3. Sánchez, C.C.S.C. La llegada de las nuevas tecnologías a la educación y sus implicaciones. Int. J. New Educ. 2019, 2. [CrossRef]

4. Olivares Carmona, K.M.; Angulo Armenta, J.; Torres Gastelú, C.A.; Madrid García, E.M. Las TIC en educación: Metaanálisis sobre investigación y líneas emergentes en México. Apert. (Guadalaj. Jal.) 2016, 8, $100-115$. [CrossRef]

5. Gómez, D.D.B.; Olivares, N.R.; Sandoval, J.R.G.; Cervantes, D.C. Tic-Innovación-Educación: Aportes, Estudios Y Reflexiones; Palibrio: Madrid, Spain, 2018.

6. Álvarez, I.M.; Olivera-Smith, M. Learning in social networks: Rationale and ideas for its implementation in Higher education. Educ. Sci. 2013, 3, 314-325. [CrossRef]

7. Manca, S.; Ranieri, M. Implicaciones de los sitios de redes sociales para la enseñanza y el aprendizaje. Dónde estamos y hacia dónde queremos ir. Educ. Y Tecnol. De La Inf. 2017, 22, 605-622. [CrossRef]

8. Marín-Díaz, V.; Sampedro-Requena, B.E.; Flores, J.F.F. ¿Inclusividad en las herramientas web 2.0? Educ. Soc. 2018, 39, 399-416. [CrossRef]

9. Ponce, I. Monográfico: Redes Sociales; Ministerio de Educación, Cultura y Deporte: Madrid, Spain, 2012; Available online: http://recursostic.educacion.es/observatorio/web/es/internet/web-20/1043-redes-sociales (accessed on 15 June 2019).

10. De Haro, J.J. Redes Sociales Para la Educación; Anaya: Madrid, Spain, 2010.

11. García, M.C.; Seco, J.A.; Del Hoyo, M. La participación de los jóvenes en las redes sociales. Anàlisi: Quad. De Comun. I Cult. 2013, 48, 95-110.

12. García, E.G.; Heredia, N.M. Redes sociales como factor incidente en el área social, personal y académica de alumnos de Educación Secundaria Obligatoria. Tendencias Pedagógicas 2018, 32, 133-146. [CrossRef]

13. Escobar, J.F.G.; Mira, Y.M.O. La globalización y la importancia de las TIC en el desarrollo social. Revista Reflexiones y Saberes 2019, 11, 2-9.

14. Siddiqui, S.; Singh, T. Las redes sociales su impacto con aspectos positivos y negativos. Rev. Int. De Tecnol. E Investig. De Apl. Inf. 2016, 5, 71-75.

15. UNESCO. Global Monitoring Report on Education. 2015. Available online: Es.unesco.org/gem-report/ (accessed on 25 February 2020). 
16. Dafoulas, G.; Shokri, A. Investigating the educational value of social learning networks: A quantitative analysis. Interact. Technol. Smart Educ. 2016, 13, 305-322. [CrossRef]

17. Galvin, S.; Greenhow, C. Educational networking: A novel discipline for improved K-12 learning based on social networks. In Educational Networking; Springer: Cham, Switzerland, 2020; pp. 3-41.

18. Arteaga, J. Las comunidades de aprendizaje y la evaluación formativa: Una experiencia significativa para transformar la práctica docente y el aprendizaje de los estudiantes desde el programa Todos a Aprender. Assensus 2018, 3, 44-59. [CrossRef]

19. Dutton, H.; Hernández, E. Redes sociales y educación. Sinectica 2012, 39. Available online: https://sinectica. iteso.mx/index.php/SINECTICA/article/view/75/67 (accessed on 25 March 2020).

20. Mayor-Ruíz, C. El Asesoramiento Pedagógico Para la Formación Docente del Profesorado Universitario; Universidad de Sevilla: Sevilla, Spain, 2007.

21. Mestres, L. Redes Sociales y Educación: Hacia la Innovación Didáctica. 2011; Available online: https: //www.educaweb.com/noticia/2011/01/31/redes-sociales-educacion-innovacion-didactica-4583/ (accessed on 25 October 2019).

22. Santamaría, F. Posibilidades pedagógicas. Redes sociales y comunidades educativas. Telos Cuad. De Comun. E Innovación 2008, 76, 99-109.

23. Mero, K.; Merchán, E.; Mackenzie, A. Las redes sociales y su importancia en la educación superior. Opuntia Brava 2018, 9, 284-298. [CrossRef]

24. Ramiro, B.E.; Montaño, P.F.; López, R.M. Del uso de las redes sociales: El caso de twitter como herramienta participativa para la intervención social. In Enfoques Y Exp. De Innovación Educ. Con Tic En Educ. Super; Allueva Pinilla and Alejandre Marco (cords.), Ed.; Prensas de la Universidad de Zaragoza: Zaragoza, Spain, 2019; pp. 299-317.

25. Artero, B.N. Available online: http://www.educaweb.com/noticia/2011/01/31/interaccion-como-ejeaprendizaje-redes-sociales-14570.html (accessed on 15 January 2020).

26. Geijo, P.M. Estilos de enseñanza: Conceptualización e Investigación. (En función de los estilos de aprendizaje de Alonso, Gallego and Honey). Rev. De Estilos De Aprendiz. 2009, 2, 3-19.

27. Garger, S.; Guild, P. Learning Styles: The Crucial Differences. Curric. Rev. 1984, 23, 9-12.

28. Donolo, D. Estudiantes, Estrategias y Contextos de Aprendizaje Presenciales y Virtuales. In Proceedings of the Congreso Virtual Latinoamericano de Educación a Distancia, Río Cuarto, Argentina, 23 March-4 April 2004; Available online: https://isfd87-bue.infd.edu.ar/sitio/upload/Chiecher20Estudiar1_1.pdf (accessed on 10 March 2020).

29. Torres, F.V. SOMECE. 2004. Available online: http://www.somece.org.mx/simposio2004/memorias/ (accessed on 12 March 2020).

30. Sandin, M.P. Investigación Cualitativa en Educación. In Fundamentos y Tradiciones; Mc Graw Hill: Madrid, Spain, 2013.

31. Flick, U. El Diseño de Investigación Cualitativa; Morata: Madrid, Spain, 2015.

32. Denzin, N.K.; Lincoln, Y.S. The SAGE Handbook of Qualitative Research; SAGE: London, UK, 2011.

33. Flick, U. Introducción a la Investigación Cualitativa, 3rd ed.; Morata: Madrid, Spain, 2012.

34. Bardin, L. Análisis de Contenido; Akal: Madrid, Spain, 2002.

35. Tójar, J.C. Investigación Cualitativa. Comprender y Actuar; La Muralla: Madrid, Spain, 2006.

36. Krippendorff, K. Metodología de Análisis de Contenido. Teoría y Práctica; Paidós: Barcelona, Spain, 2002.

37. McMillan, J.H.; Schumacher, S. Investigación Educativa. In Una Introducción Conceptual, 5th ed.; Pearson Educación: Madrid, Spain, 2012.

38. Moolenaar, N.M. A social network perspective on teacher collaboration in schools: Theory, methodology, and applications. Am. J. Educ. 2012, 119, 7-39. [CrossRef]

39. Richter, J.; Dawley, L. Social network knowledge construction: Emerging virtual world pedagogy. Horizen 2009, 17, 109-121.

40. Hunter, L.J.; Hall, C.M. A survey of K-12 teachers' utilization of social networks as a professional resource. Educ. Inf. Technol. 2018, 23, 633-658. [CrossRef]

41. Ozkan, B.; McKenzie, B. Social networking tools for teacher education. In Society for Information Technology $\mathcal{E}$ Teacher Education International Conference; Association for the Advancement of Computing in Education (AACE): Waynesville, NC, USA, 2008; pp. 2772-2776. 
42. Vidal, C.E.; Martínez, J.G.; Fortuño, M.L.; Cervera, M.G. Actitudes y expectativas del uso educativo de las redes sociales en los alumnos universitarios. RUSC Univ. Knowl. Soc. J. 2011, 8, 171-185.

43. Higueras-Rodríguez, L.; Martín-Romera, A.; Molina, E. Las redes sociales como vía para la formación docente en el uso de herramientas lúdico/didácticas. In Experiencias Pedagógicas e Innovación Educativa. Aportaciones Desde la Praxis Docente e Investigadora; Eloy, L.M., David, C.S., Antonio, H.M.P., Laura, M.G., Alicia, J.M., Eds.; Octaedro: Barcelona, Spain, 2018; pp. 2943-2951.

44. Moghavvemi, S.; Sulaiman, A.; Jaafar, N.I.; Kasem, N. Las redes sociales como una herramienta de aprendizaje complementaria para la enseñanza y el aprendizaje: El caso de youtube. Int. J. Manag. Educ. 2018, 16, 37-42. [CrossRef]

45. Trujillo, J. Redes Sociales y Educación; Universidad de Málaga: Málaga, Spain, 2014.

46. Çam, E.; Isbulan, O. A new addiction for teacher candidates: Social networks. Turk. Online J. Educ. Technol. -Tojet 2012, 11, 14-19.

47. Ranieri, M.; Manca, S.; Fini, A. Why (and how) do teachers engage in social networks? An exploratory study of professional use of $\mathrm{F}$ acebook and its implications for lifelong learning. Br. J. Educ. Technol. 2012, 43, 754-769. [CrossRef]

48. Marín, V.; Cabero, J. Las redes sociales en educación: Desde la innovación a la investigación educativa. Ried. Rev. Iboeroamericana De Educ. A Distancia 2019, 22, 25-33. [CrossRef]

49. Hunter, L.J.; Hall, C.M. Una encuesta sobre la utilización de las redes sociales por parte de los maestros de K-12 como recurso profesional. Educ. Y Tecnol. De La Inf. 2018, 23, 633-658. [CrossRef]

50. Prestridge, S. Categorizar el uso que los docentes hacen de las redes sociales para su aprendizaje profesional: Un paradigma de aprendizaje profesional autogenerado. Comput. Y Educ. 2019, 129, 143-158. [CrossRef]

(C) 2020 by the authors. Licensee MDPI, Basel, Switzerland. This article is an open access article distributed under the terms and conditions of the Creative Commons Attribution (CC BY) license (http://creativecommons.org/licenses/by/4.0/). 